www.cjes.eu

\title{
Preschool teacher education as an example of an open social system
}

Belkıs Tekmen*

Suggested Citation:

Educational Science 12

Abstract 
1. Introduction 
2. Components of this open social system: Recent regulations on the structure and content

2.1. Acceptance to the Program 
2.2. Recruitment of the Graduates

2.3. Faculty Development 
3. Current Issues in Preschool Teacher Education in Turkey

3.1. Candidates' Profiles 
3.2. Transferring the Theory into Practice

3.3. Teacher Competencies 


\section{Conclusion}




\section{References}

Social and Behavioral Sciences, 9

Procedia -

Ilkogretmen, 16

International Journal of

Human Sciences, 4

International Journal of Human Sciences, 4

Dogru baslangic: Turkiye'de okul oncesi egitim, (Start Right: Preschool Education in Turkey) 
on teaching

Education Policy Analysis Archives, 8

International Journal of Educational Development, 26

Journal of Hacettepe University Faculty of Education, 23

Egitim fakultesi ogretmen yetistirme lisans programlari

Educational administration: Theory, research, and practice

Quality improvement in early childhood teacher education: Faculty perspectives and recommendations for the future

Exploring your role: A practitioner's introduction to early childhood education

Early Child Development and Care, 180

2050'ye dogru nufusbilim ve yonetim: Egitim sistemine bakis

Procedia Social and Behavioral Sciences, 15

Turk Egitim Bilimleri Dergisi, 5

Development, 47

Monographs of the Society for Research in Child

Assurance in Education, 14

Quality

Milli Egitim Bakanligi egitimi arastirma ve gelistirme dairesi baskanligi: Hedef 2009

Into adulthood: A study of the effects of head start

World Applied Science Journal, 7

Evaluation of preschool teacher education program in Turkey: Academicians' perspective 
Early education quality: Higher teacher qualifications for better learning environments : A review of the literature

Milli Egitim Dergisi 